研 究 速 報

\title{
アニメーションを用いた制御結果の表示*
}

足立 修一**

\section{Demonstration of Control Results by Using Animation*}

Shuichi ADACHI**

\section{1.はじめに}

設計された制御系の性能を示す方法は，大きく分けて， 計算機を利用した数值シミュレーション実験と実験装置 あるいは実機を用いた制御実験の二通りある。あちろん 実験装置などを用いて制御性能を確認する重要性は誰し あ認めるところであるが, 大学等の教育機関では, 経済 的あるいは技術的な理由から，必ずしあすぐに高精度な 実験を行えないことが多い.しかしながら，数值実験に よるグラフの呈示だけでは, システム制御工学の教育効 果は期待できない.

本報告では, 制御結果をアニメーション化するととに より, 実際のモノの動きを視覚化する方法を提案する.

この背景には, 高速な計算機が比較的安価に利用できる ようになり，今後積極的にシステム制御工学の教育にも 計算機の利用が望まれている点が挙げられる。 とくに, 最先端の制御理論を手軽に模擬実験できる手段としてア ニメーションは有効である.

こてでは，非線形システムに対する制御系設計理論が 活発に研究されている点に着目し, 非線形システムの一 例としてシーソーシステムを採用し, 非線形制御系の設 計を行う。そして, 制御結果をマッキントッシュ計算機 (Apple 社) 上飞, MATLAB (The Math Works 社) とQuick Time (Apple 社) というソフトウェアを用い てアニメーション化した例を報告する. Quick Timeを 用いることにより，サンプリング周期を陽に考慮するこ とができるため，実際の動きに近いアニメーションを作 成することができ, 制御の教育上, 有用であると思われ る.

\footnotetext{
* 原稿受付 1994 年 2 月 10 日

** 宇都宮大学 工学部 Faculty of Engineering, Utsunomiya University ; 2753 Ishiimachi, Utsunomiya city, Tochigi 321, JAPAN
}

Key Words : animation, control education, visualization, nonlinear control system, MATLAB.

\section{2. シーソーシステム}

Fig. 1 亿示すシーソーシステムを制御対象とする1),2).

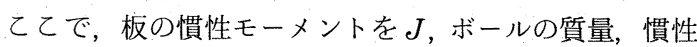
モーメントをそれぞれ $M, J_{b}$, ボールの半径を $R$, 重力 加速度を $G$, 板の角度を $\theta$, ボールの位置を $r$, 板に加え られるトルクをてとすると, 状態方程式

$$
\left\{\begin{aligned}
\frac{d}{d t} \boldsymbol{x} & =\boldsymbol{f}(\boldsymbol{x})+g(\boldsymbol{x}) u \\
y & =h(\boldsymbol{x})
\end{aligned}\right.
$$

が得られる。ただし，入力 $u$ は非線形フィードバック

$$
\tau=2 M r \dot{r} \dot{\theta}+M G r \cos \theta+\left(M r^{2}+J+J_{b}\right) u
$$

により定義される新しい入力である．また，

$$
\boldsymbol{f}(\boldsymbol{x})=\left[\begin{array}{c}
x_{2} \\
B\left(x_{1} x_{4}^{2}-G \sin x_{3}\right) \\
x_{4} \\
0
\end{array}\right], \quad g(\boldsymbol{x})=\left[\begin{array}{l}
0 \\
0 \\
0 \\
1
\end{array}\right]
$$

$$
h(\boldsymbol{x})=x_{1}
$$

と打いた。なお，

$$
\begin{aligned}
& \boldsymbol{x}=\left(\begin{array}{llll}
x_{1} & x_{2} & x_{3} & x_{4}
\end{array}\right)^{\mathrm{T}}=\left(\begin{array}{llll}
r & \dot{r} & \theta & \dot{\theta}
\end{array}\right)^{\mathrm{T}} \\
& B=\frac{M}{\frac{J_{b}}{R^{2}}+M}
\end{aligned}
$$

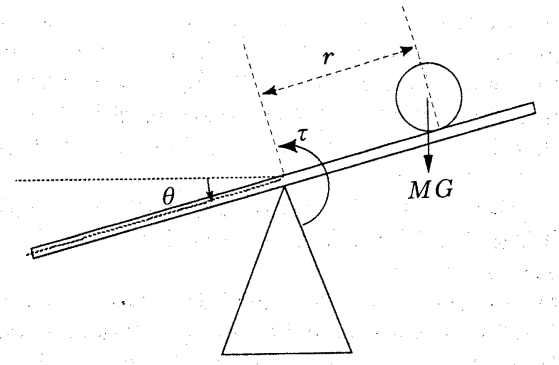

Fig. 1 Seesaw system 
である。乙の非線形システムの相対次数は welldefined でないため, 厳密な入出力線形化を適用できず, また integrability 条件を満たさないため, 状態の線形 化屯行えないてとが知られている. したがって, シーソ 一システムは比較的構造が簡単でありながら, 近年研究 が盛んに行われている厳密な線形化が適用できない典型 的な例題である. 本報告では, Kokotovic らが提案し た入出力近似線形化 ${ }^{1)}$ を用いて非線形制御系を設計する が，詳細は省略する.

\section{3. アニメーションの作成}

アニメーションの作成手順を以下に示す.

Step 1 非線形コントローラ（近似入出力線形化により 設計）により制御されたボールの位置とシーソ 一の角度を計算する。

Step 2 MATLAB のPLOT コマンドを用いて, 各時 刻に拈けるボールの位置とシーソーの角度より, アニメーションのセル（アニメーションのひと コマのとと）を作成する3).

Step 3 作成されたセルを, アニメーション作成用のソ フトゥエア (Magic : MacroMind/Paracomp 社）に取り込み，背景などを書き加え，処理す る.

Step 4 Quick Time を用いるととによって, アニメー ションのサンプリング時間（コマでとの時間間 隔のこと）を指定し，実際の動きを再現する.

\section{4. 例 題}

シーソーシステムの物理パラメータを $M=0.05(\mathrm{~kg})$, $R=0.01(\mathrm{~m}), J=0.02\left(\mathrm{~kg} \cdot \mathrm{m}^{2}\right), J_{b}=2 \times 10^{-6}(\mathrm{~kg} \cdot$ $\left.\mathrm{m}^{2}\right), G=9.8\left(\mathrm{~m} / \mathrm{s}^{2}\right)$ として数值シミュレーションを 行った. このとき, MATLABにより描かれたアニメ ーションの一例を Fig. 2 に示した. また, 背景を書き

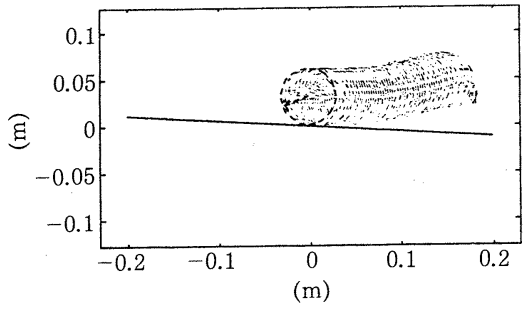

Fig. 2 An example of animation using MATLAB

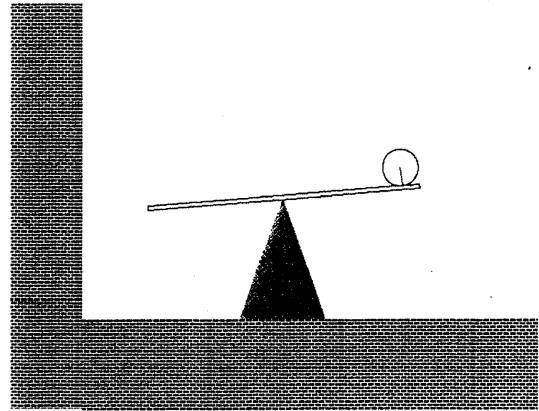

Fig. 3 A refined picture for animation

加えたセルの一例を Fig. 3 に示した. アニメーション を紙面に紹介することはできないが，実際の動きに近い 結果が得られた.

\section{5. おわりに}

本報告では，アニメーションを用いて制御結果を表示 する方法を提案した，本方法では，サンプリング時間を 考慮してアニメーションを作成できるので, 実機と同じ 時間スケールが実現できた。現時点ではアニメーション 作成に非常に時間がかかるという問題点があるが，今後 ソフトウエアの進歩により，乙れは解決できると考えて いる. また本報告では, 制御結果をすべて計算した後, アニメーションの作成を行っているが（すなわち，オフ ライン処理), 今後, 制御結果をオンライン処理して, アニメーションを作成していきたいと考えている. 本報 告で提案したような，計算機という仮想世界の上で制御 実験を模擬する方法は，今後制御工学の教育においてす, 重要になっていくあのと思われる. 最後に, ソフトウエ アの作成にご協力いただいた本学佐々木君, 須永君に感 謝します。

\section{参 考 文 献}

1) J. Hauser, S. Sastry and P. Kokotovic : Nonlinear Control via Approximate Input-Output Linearization : The Ball and Beam Example; IEEE Trans. on Automat. Contr., Vol. 37, No. 3, pp. 392 398 (1992)

2) P. V. Kokotovic: The Joy of Feedback : Nonlinear and Adaptive; IEEE Control Systems Magazine, pp. $7 \sim 16$ (1992)

3) 足立, 佐々木, 須永 : MATLAB を用いた非線形制御系の アニメーション; 第 36 回自動制御連合講演会前刷, pp. 169 170 (1993). 